\title{
UNIFIED APPROACH TO ESTIMATION OF SEISMIC RESISTANCE OF CONFINED MASONRY BUILDINGS AND REINFORCED CONCRETE FRAME BUILDINGS WITH NONBEARING INFILL
}

\author{
Oleksiy Murashko ${ }^{1}$ \\ ${ }^{1}$ Department of Reinforced Concrete and Masonry Structures, Odessa State Academy of Civil Engineering and \\ Architecture, Odessa, Ukraine
}

\begin{abstract}
The work is dedicated to designing of unified approach to estimation of actual seismic resistance of structures with reinforced concrete flat slabs frames with diaphragms and cores and confined masonry buildings. This investigation is on the agenda, because of large non-conformities of field test results by determination of natural vibration periods of buildings to computational analysis results. Some times this differences exceeds 100\%. On the other side difference between field tests and FEM (Finite element method) models for confined masonry buildings does not exceed 8\%. The main reason of such differences is nonbearing infill of reinforced concrete frames that mainly consists of AAC (Aerated Autoclave Concrete) that work as a diaphragm. The final purpose of computer modeling of buildings behavior under seismic effects is creation of a reliable model of a building describing its real operation, and it was decided to carry out a series of computational and field experiments for development of recommendations for creation of a reliable model of buildings that takes into account nonbearing elements. Paper describes series of calculations and field tests of structures with reinforced concrete flat slabs frames with diaphragms and cores and confined masonry buildings aimed on harmonization of calculation schemes. And unified approach for both of the schemes helps to solve the problem of disparity. This work is a continuation of investigations on development of estimation system of actual seismic resistance of buildings and it is a component of the second level of estimation - certification of seismic stability.
\end{abstract}

Keywords: Confined Masonry, Flat Slab, Computational Model, , Nonstructural Elements, Vibration Tests

\section{INTRODUCTION}

At present two types of structural schemes have become widespread in seismic regions of Ukraine: confined masonry buildings and reinforced concrete buildings with girderless frames with diaphragms and cores. Analogous situation is observed in many countries in construction of 8-20-storey buildings with low and moderate seismic hazard. In computation and designing of buildings related to these schemes there are two different approaches based upon the difference of ratio of bearing capacity of infill elements and reinforced concrete structures. It is widely accepted that in confined masonry buildings cooperation of masonry and reinforced concrete elements is provided at all stages up to the utmost stage, while in buildings with girderless frame walls filling performs exceptionally load function.

If for the first scheme such cooperation of infill and frame is obvious, for girderless frame such operation of infill is disputable, that is confirmed by the results of many investigations and analysis of earthquake consequences. Such simple comparison of limit deformations of aerated concrete walls, of interstorydrifts and gaps between nonbearing elements is evidence of serious non-coordination of these parameters [1]. $0.3-0.5 \%$ is for aerated concrete walls of various length, $2.5-3 \%$ - limit interstorydriftsof reinforced concrete girderless frame with/without stiffening diaphragms [2].
Earthquakes demonstrate justifiability or non-justifiability of offers on operation of structure. And analysis of consequences of a series of earthquakes showed that elements considered non-bearing under highly intensive seismic effects are included into operation of the building and assume a part of seismic load. Ignorance of this factor may involve serious damages of bearing elements [3].On the example of the Wenchuan earthquake consequences it's clear that irregular arrangement of non-bearing infill on the level of the first story caused damage of reinforced concrete columns over perimeter of the object [4]. It testifies that non-bearing elements redistribute seismic load among bearing ones and this effect is not taken into account in computation when filling is modeled by load. (fig -1)

Consequently, analysis of earthquakes showed that elements considered as non-bearing under highly intensive seismic effects are included into operation of the building and assume a part of seismic load. . Ignorance of this factor may involve serious damages of bearing elements.

Proceeding from the abovementioned, the following hypothesis was formulated. Buildings with girderless frame and confined masonry buildings can be referred to braced systems with redundant connections. 

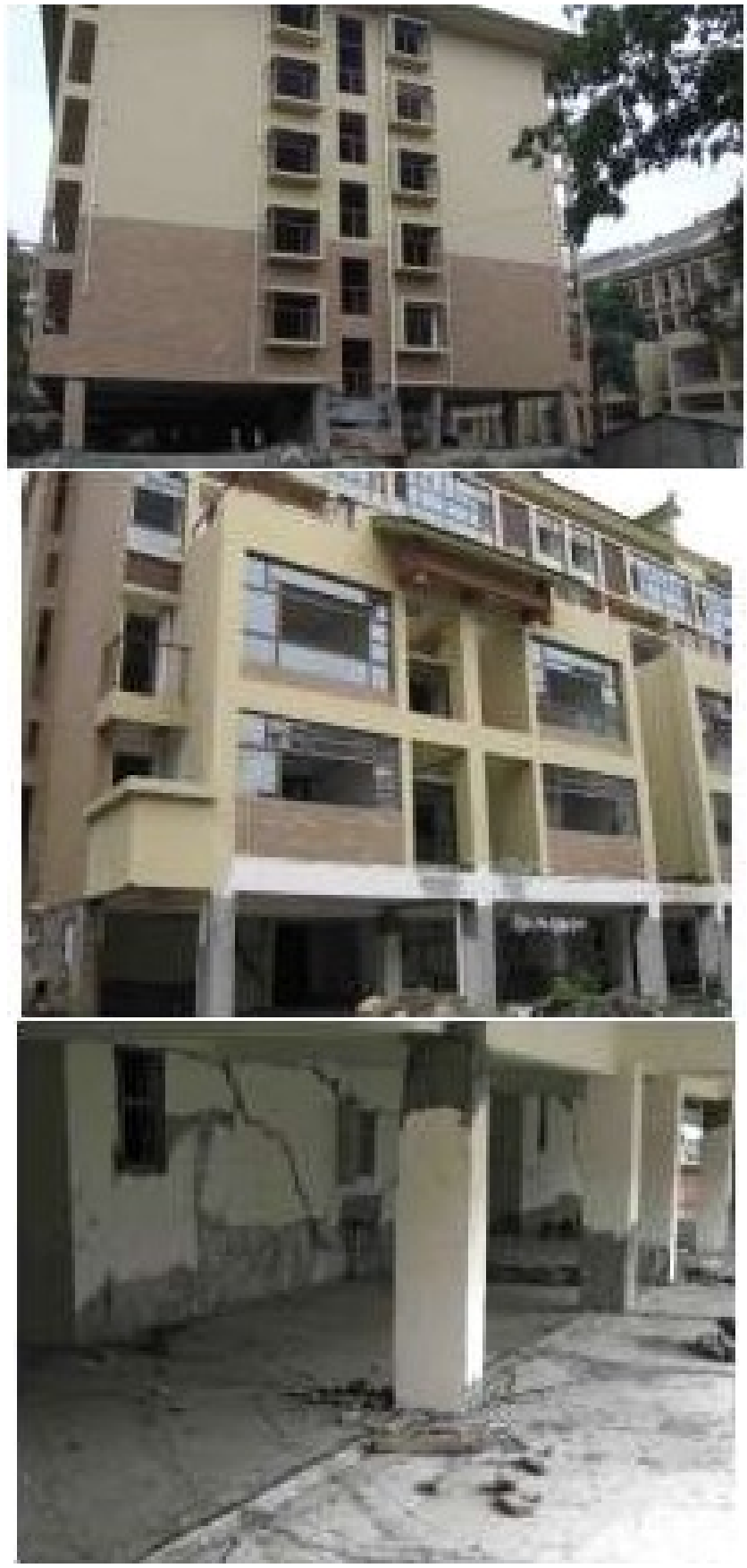

Fig - 1. Consequences of the Wenchuan earthquake

To check the advanced hypothesis it is offered to carry out a serious of the following computational and field investigations.

1. To carry out field investigations of a confined masonry building and a building with girderless frame.

2. To carry out computational investigations of tested buildings and for the building with girderless frame in two versions, considering and ignoring stiffness of "nonbearing" elements.

\section{FIELD INVESTIGATIONS OF OBJECTS}

A number of buildings with girderless frame and a threesection dwelling complex with confined masonry structural scheme were tested. Detailed description of the test method is in [5]. The article contains results obtained for two of subjects of investigation: one confined masonry and one with girderless frame. The test method and brief characteristics of the object are given below.

\subsection{Test Method}

Tests were carried out by excitation of vibrations in building structures in three ways:

1. Microseisms from local seismic noises.

2. Impacts by tamper.

3. Impacts by load fixed to a hoisting crane.

All three ways showed equal values of vibration periods on both objects.

For 12-story confined masonry building the period of the first shape of natural mode was 0.707 , for 19 -story building it varied from 1.413 up to 1.17 second. Test results are given in Table1.

\subsection{Confined Masonry Building}

The first object is 12-story dwelling house with confined masonry structural scheme (Plan of a typical storey and scheme of a sections blocking are given in the figure 2).

Proceeding from the record given in Fig-3 it's clear that there are disturbances in the vibration process caused by close location of cobble-stone pavement, on which traffic flow is permanently moving. The rest of objects do not have similar disturbances.
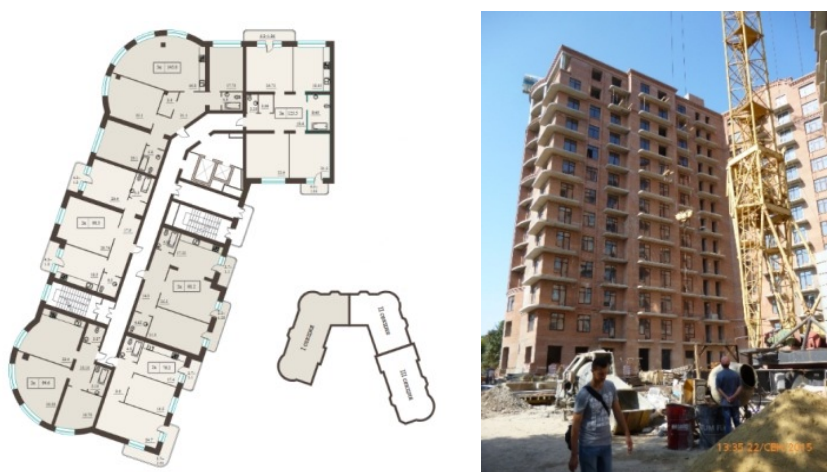

Fig -2. Plan of a typical storey, blocking of sections and photographic evidence of the object CM-1

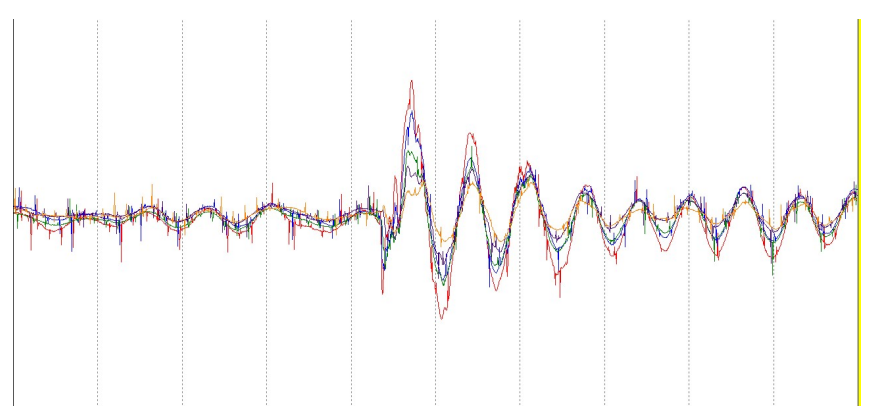

Fig-3. Record obtained for the object under investigation 


\subsection{Building with Girderless Frame with}

\section{Diaphragms and Core}

The second object is 19-storey building with girderless frame and aerated concrete filling with masonry made of ceramic bricks.
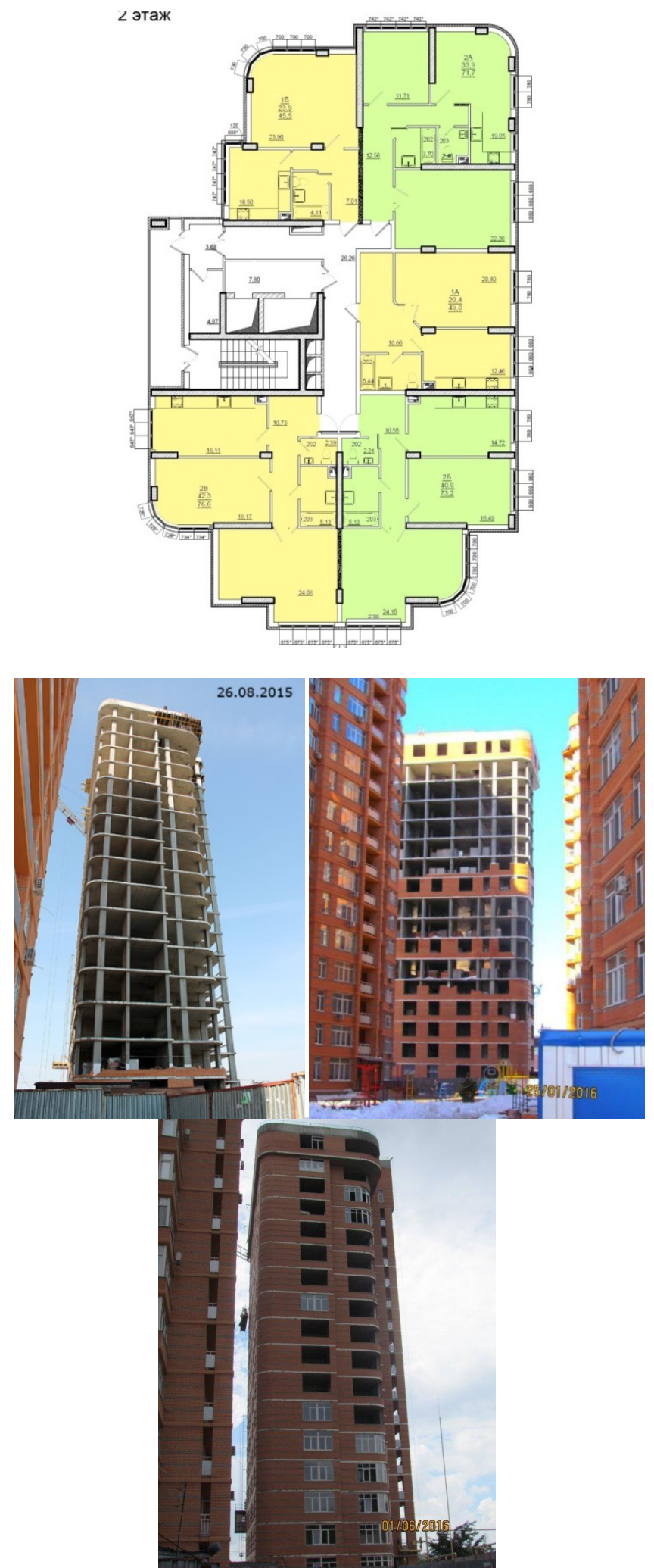

Fig-4. Plan of typical floor and photo of the object (Respectively F-1, F-2, F-3)
Outstanding feature of this stage of tests is that reinforced concrete frame and wall filling in this building were not constructed in parallel (as it is usually done with an advance in $3-5$ storeys), but into completely constructed reinforced concrete frame.

Carried out field tests of buildings showed that filling has a significant influence upon operation of the frame (Table 1).

\section{COMPUTATIONAL INVESTIGATIONS}

All computations were made in program complexes MONOMAKH and LIRA, in which finite-element method was implemented. Computations were made under the spectral technique.

\subsection{Confined Masonry Building}

Computation of the confined masonry building was made under the classical scheme, in which operation of masonry as bearing element is taken into account. General view of the design model is given in Fig.5.

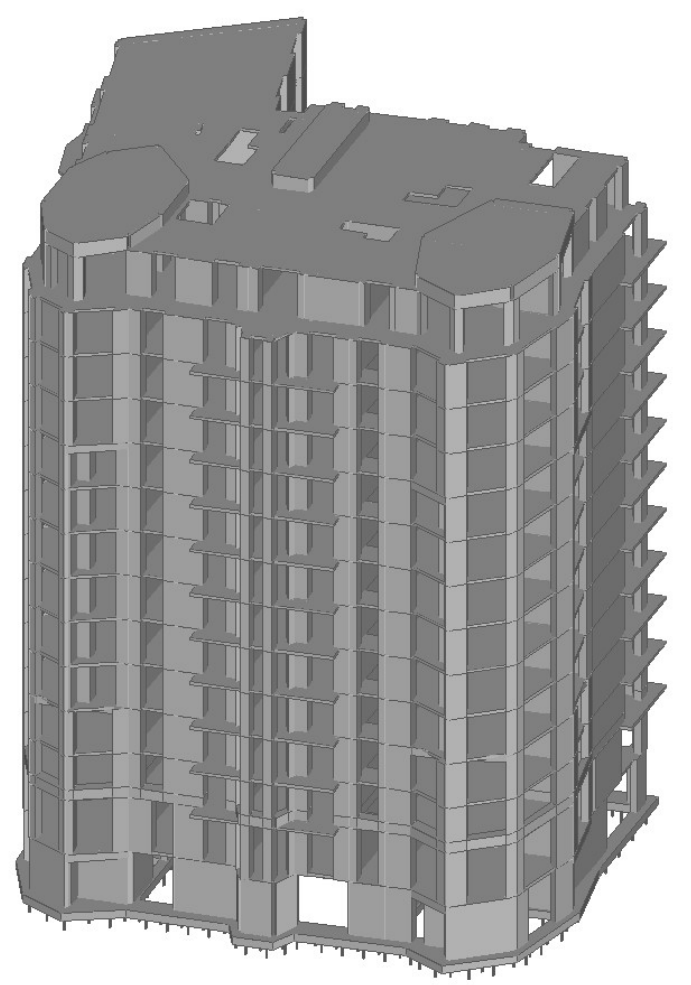

Fig-5. Computation scheme of the confined masonry buildingCM-1

\subsection{Reinforced Concrete Girderless Frame with Diaphragms and Cores}

Proceeding from the advanced hypothesis computations are subdivided into 2 stages:

1. Under classical approach (non-bearing filling participates in operation as load);

2. Under offered method (non-bearing filling participates in operation of building). 
Computation is made under classical scheme (non-bearing filling participates in operation as load). Period of the first shape of natural mode was $1.6533 \mathrm{sec}$. for scheme with filling for the full height and $1.448 \mathrm{sec}$. for scheme with filling at the level of the first floor.
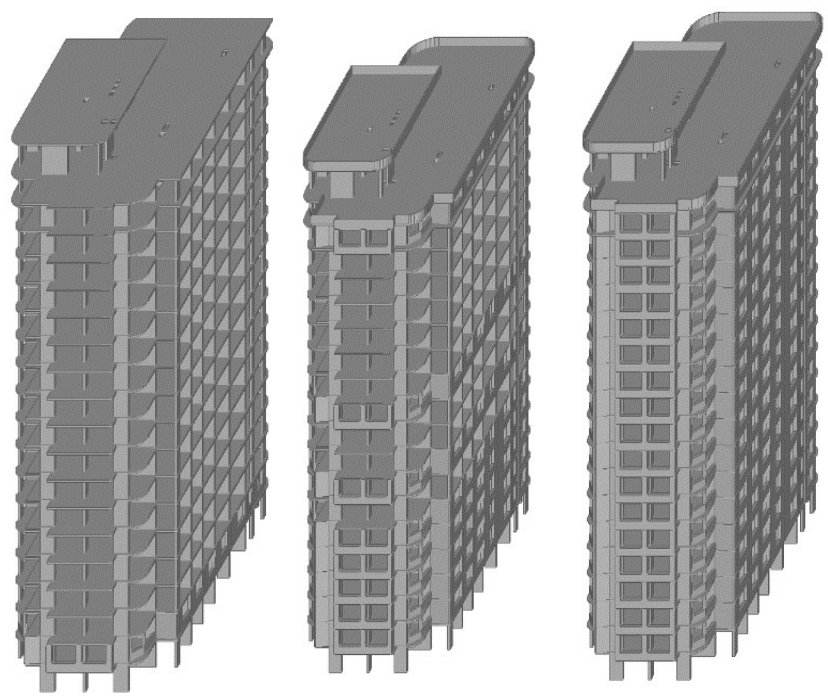

Fig -6. Computation schemes of the object (Respectively F$1, \mathrm{~F}-2, \mathrm{~F}-3$ )

The second group of computations was made proceeding from the advanced hypothesis: two-layer filling made of aerated concrete and brick masonry was modelled with lamellar elements of specified stiffening. Characteristics of masonry: stone M175 on solution M50, thickness $120 \mathrm{~mm}$, elasticity module $370000 \mathrm{t} / \mathrm{m} 2$, aerated concrete of grade D500 $300 \mathrm{~mm}$ thick, elasticity module $100000 \mathrm{t} / \mathrm{m} 2$.

Total thickness for filling elements was $420 \mathrm{~mm}$ and specified elasticity module $-177000 \mathrm{t} / \mathrm{m} 2$.

Obtained results showed that periods of first shapes of natural mode for buildings with fully performed filling and filling at the level of the first storey were: 1.183 and 1.415 sec (around 20\%)

Table -1. Results of field investigations and computation

\begin{tabular}{|l|l|l|l|}
\hline & Tests, sec & $\begin{array}{l}\text { Computation 1, } \\
\text { sec }\end{array}$ & $\begin{array}{l}\text { Computation 2, } \\
\text { sec }\end{array}$ \\
\hline $\mathrm{CM}$ & 0.7 & - & 0.7103 \\
\hline $\mathrm{K}-1$ & 1.41 & 1.448 & 1.415 \\
\hline $\mathrm{K}-2$ & 1.27 & 1.577 & 1.252 \\
\hline $\mathrm{K}-3$ & 1.17 & 1.653 & 1.183 \\
\hline
\end{tabular}

According to the results of analysis of data given in Table 1 it shall be noted that the difference between results obtained during tests from design model made based on classical approach was more than $40 \%$, while taking into account of non-bearing filling in the operation of building results into differences not exceeding $2 \%$. For all tested buildings $-8 \%$.

Consequently, having compared two sets of field tests of buildings with their design models it turns out that both in confined masonry buildings and buildings with reinforced concrete frame almost full conformity of computational and field test results van be achieved under low intensive seismic effects, taking into account material of walls in operation.

If for confined masonry buildings such computation concept is considered classical and generally accepted, for reinforced concrete ones operation of wall infill in the form of loads is widely used that is not true to life.

Results of all investigations carried out showed that the difference in durations of vibration periods determined experimentally and numerically is up to 2 and more times for buildings with girderless frame and $1-8 \%$ for the confined masonry building. At that if the design scheme takes into account non-bearing filling not only as loads, but as real stiffening, the differences with the field experiment will not exceed $8 \%$.

With full conformity of the results obtained from computations and field tests it shall be noted that test were conducted at low level of effects. Therefore obtained results express operation of the building corresponding to WE (weak earthquake) [DBN].

For this reason for determination of seismic stability of buildings corresponding to higher level of DE and MDE (design earthquake and maximum design earthquake respectively), additional investigations are required.

\section{CONCLUSION}

Consequently, considering estimation of seismic stability of confined masonry buildings and buildings with girderless frame with level of effects corresponding to WE (weak earthquake) the only approach can be applied. With levels of effects of Design Earthquake and Maximum Considered Earthquake the differential approach is required. At that differentiation is not large-scale, but consists in different approach to determination of parameters of elements simulating operation of wall filling.

As a practical recommendation for design engineers it shall be noted that when designing buildings with girderless frame and non-bearing wall infill special attention shall be paid to regularity of location of non-bearing filling.

\section{REFERENCES}

[1] Penna, A., Magenes, G., Calvi, G.M. and Costa, A.A. (2008) Seismic performance of AAC infill and bearing walls with different reinforcement solutions. In: Proc. 14th International Brick and Block Masonry Conference, Sydney, Australia

[2] DBN B.1.1-12: 2014. Construction in seismic regions of Ukraine / Minregionbud Ukraini. - Kiyev: 2014. $110 \mathrm{p}$.

[3] http://www.iitk.ac.in/nicee/wcee/article/WCEE2012_0 183.pdf 
[4] http://framedinfill.org/resources/technical-

literature/observationsfromrecentearthquakes/

[5] O. Murashko, V. Dorofeev, O.Mihailov, V. Yegupov, N. Mihailova Problem of non-conformity of design model and results of vibration tests of multistory buildings with girderless construction "OVIDIUS" UNIVERSITY ANNALS - CONSTANTZA Year XVII- Issue 17 (2015) Series: CIVIL ENGINEERING pp55-60

\section{BIOGRAPHIE}

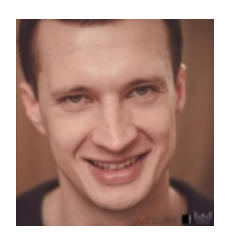

Oleksiy MurashkoPhD, associate professor of the Department of Reinforced Concrete and Masonry Structures, Odessa State Academy of Civil Engineering and Architecture, (Odessa, Ukraine). Author of more than 50 publications devoted to the development of three-tiered system for actual aseismic resistance assessment of multistory structures 